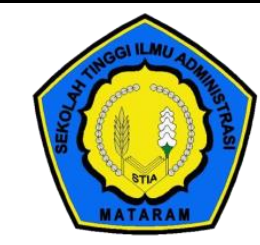

Jurnal Tata Sejuta Vol. 4, No. 2, September 2018

Jurnal Tata Sejuta STIA MATARAM

http://ejurnalstiamataram.ac.id

P-ISSN 2442-9023, E-ISSN 2615-0670

\title{
ANALISIS AGENDA SETTING TERHADAP KEBIJAKAN PEMBENTUKAN DAERAH OTONOMI BARU (DOB) (STUDI KASUS PERENCANAAN PEMEKARAN DI KABUPATEN BUNGO)
}

\author{
Helva Rahmi ${ }^{1 \times}$ \\ 1 Universitas Diponegoro Semarang
}

\section{Info Artikel}

Sejarah Artikel:

Diterima: 27 Juli 2018

Disetujui: 25 September

2018

Dipublikasikan: 29

September 2018

Kata kunci:

Agenda Setting,

Perumusan

Kebijakan,

Pembentukan

Daerah Otonomi

Baru

\begin{abstract}
Abstrak
Tulisan ini merupakan hasil penelitian mengenai tahapan kebijakan pembentukan Daerah otonomi Baru di Kabupaten Bungo. Pemekaran wilayah merupakan sebuah produk kebijakan publik, sebagai upaya pemerintah untuk memecahkan masalah publik agar tercapainya pelayanan yang efektif dan efisien. Penelitian ini menggunakan pendekatan kualitatif dengan menggabungkan teknik observasi, wawancara dan studi dokumen. Tujuan penelitian ini untuk melihat tahap-tahap kebijakan pembentukan Daerah Otonomi Baru dan faktor-faktor yang menghambat tahap-tahap perumusan kebijakan pembentukan Daerah Otonomi Baru di Kabupaten Bungo. Hasil dari penelitian ini menunjukan bahwa tahapan kebijakan pembentukan Daerah Otonomi Baru di Kabupaten Bungo merupakan tahapan yang cukup rumit dan sudah memakan waktu yang cukup lama dimana dari sebuah kesepakatan bersama menjadi sebuah kebijakan publik, banyak persyaratan yang harus disesuaikan dengan kondisi dan kemampuan daerah Kabupaten Bungo itu sendiri, dan juga berbagai polemik publik yang dihadapi selama tahapan pembentukan Daerah Otonom Baru.
\end{abstract}

\section{ANALYSIS OF AGENDA SETTING ON THE POLICY OF FORMING NEW AUTONOMOUS REGIONS (CASE STUDY OF EXPANSION PLANNING IN BUNGO REGENCY)}

Keywords:
Agenda Setting,
Policy
Formulation,
Establishment
of New
Autonomous
Region

\begin{abstract}
This is the result of research on the stages of policy formation New Autonomous Region in Bungo. The regional growth is a product of public policy, as the government attempts to solve public problems in order to achieve an effective and efficient service. This study used a qualitative approach by combining the techniques of observation, interviews and document research. The purpose of this study to look at the stages of policy formation of the New Autonomous Region and the factors that hinder the stages of policy formulation formation of New Autonomous Region in Bungo. The results of this study indicate that the stages of policy formation Autonomous Region New Bungo is a stage that is quite complicated and it takes quite a long time which of a collective agreement becomes a public policy, many of the
\end{abstract}


requirements that must be adapted to the conditions and capacity Bungo it itself, as well as various public polemics encountered during the stages of the formation of new autonomous regions.

(C) 2018 Sekolah Tinggi IImu Administrasi Mataram

\footnotetext{
${ }^{\otimes}$ Alamat korespondensi:

Helva.rahmi@gmail.com
}

\section{PENDAHULUAN}

Penyelenggaraan pemerintahan yang baru memberikan peran lebih besar kepada Pemerintahan Daerah mulai diberlakukan di Indonesia yang diimplementasikan atas dasar UU No. 22/1999 direvisi menjadi UU No.32/2004, kemudian direvisi ulang menjadi UU No.23/2014 Tentang Pemerintahan Daerah. Untuk memaksimalkan Desentralisasi sesuai dengan Undang-Undang tersebut, Penataan Daerah Otonomi Baru (DOB) menjadi salah satu isu penting yang sampai sekarang masih menjadi fokus Pemerintah. Penataan DOB sampai saat ini masih sangat identik dengan pemekaran wilayah, mengarah pada penghapusan dan penggabungan wilayah seperti diatur dalam PP No.129/2000 Tentang persyaratan pembentukan dan kriteria pemekaran, penghapusan, dan penggabungan daerah yang kemudian diganti dengan PP No.78/2007 Tentang tata cara pembentukan, penghapusan, dan penggabungan daerah.

Didalam UU No.23/2014 Tentang Pemerintah Daerah pada pasal 31 perihal Penataan Derah pada ayat (1) menyatakan bahwa dalam pelaksanaan Desentralisasi dilakukan penataan daerah, selanjutnya pada ayat menjelaskan penataan daerah yang dimaksud pada ayat (1) ditujukan untuk:

(a) Mewujudkan efektivitas penyelenggaraan Pemerintahan Daerah;

(b) Mempercepat peningkatan kesejahteraan masyarakat;

(c) Mempercepat peningkatan kualitas pelayanan publik;

(d) Meningkatkan kualitas tata kelola pemerintahan;

(e) Meningkatkan daya saing nasional dan daya saing Daerah; dan

(f) Memelihara keunikan adat istiadat, tradisi, dan budaya Daerah.

Era reformasi yang ditandai dengan meningkatnya tuntutan untuk melakukan pemekaran daerah berjalan seiring dengan regulasi pembentukan daerah otonom baru yang dianggap lebih mudah daripada waktu sebelumnya. Dimotivasi oleh percepatan pertumbuhan demokrasi (lokal), Pada Pasal 6 ayat (1) dan (2) 
UU No.22/1999 Tentang Pemerintahan Daerah disebutkan "Daerah dapat dihapus dan digabung dengan daerah lain, dan Daerah Otonom dapat dimekarkan menjadi lebih dari satu daerah jika dipandang sesuai dengan perkembangan daerah".

Didalam UU. No.32/2004 perihal pemekaran daerah diatur pada Pasal 46 ayat (3) dan (4), sebagai berikut: Pembentukan daerah dapat berupa penggabungan beberapa daerah atau bagian daerah yang bersandingan atau pemekaran dari satu daerah menjadi dua daerah atau lebih. Pada ayat (4) disebutkan bahwa pemekaran dari satu daerah menjadi dua daerah atau lebih sebagaimana dimaksud pada ayat (3) dapat dilakukan setelah mencapai batas maksimal usia penyelenggaraan pemerintahan. Sementara, pada Pasal 5 ayat (1) disebutkan: Pembentukan daerah sebagaimana dimaksud pada pasal 4 harus memenuhi syarat administratif, teknis dan fisik kewilayahan.

Kemudian didalam UU No.23/2014 hasil revisi dari UU No.32/2004 Tentang Pemerintah Daerah pada Pasal 32 perihal Pembentukan Daerah pada ayat (1) pembentukan daerah yang dimaksud berupa pemekaran daerah dan penggabungan daerah, selanjutnya ayat (2) menyatakan pembentukan daerah yang dimaksud mencakup pembentukan daerah Provinsi dan pembentukan daerah Kabupaten/Kota.

Selanjutnya pada pasal 33 perihal pemekaran daerah ayat (1) pemekaran daerah yang dimaksud berupa pemecahan daerah provinsi atau daerah kabupaten/kota untuk menjadi dua atau lebih Daerah baru; atau penggabungan bagian daerah dari daerah yang bersanding dalam 1 (satu) daerah provinsi menjadi satu daerah baru. Kemudian pada ayat (2) dijelaskan bahwa pemekaran daerah sebagaimana dimaksud pada ayat (1) dilakukan melalui tahapan daerah persiapan provinsi atau daerah persiapan kabupaten/kota. Pembentukan daerah persiapan sebagaimana dimaksud pada ayat (2) harus memenuhi persyaratan dasar dan persyaratan administratif.

Kemudian pada Pasal 34 menyatakan bahwa persyaratan dasar sebagaimana dimaksud dalam Pasal 33 ayat (3) meliputi: persyaratan dasar kewilayahan; dan persyaratan dasar kapasitas Daerah. Selanjutnya ayat (2) persyaratan dasar kewilayahan sebagaimana dimaksud pada ayat (1) meliputi: luas wilayah minimal, jumlah penduduk minimal, batas wilayah, cakupan wilayah dan batas usia minimal daerah provinsi, daerah kabupaten/kota, dan kecamatan. 
Kemudian ayat (2) persyaratan dasar kapasitas daerah sebagaimana dimaksud pada ayat (1) adalah kemampuan daerah untuk berkembang dalam mewujudkan kesejahteraan masyarakat.

Dapat terlihat ada perbedaan antara UU No.32/2004 dengan UU No.23/2014 yang terletak pada pasal 33 ayat (2) yang menyatakan bahwa pemekaran daerah sebagaimana dimaksud dilakukan melalui tahapan Daerah Persiapan provinsi atau Daerah Persiapan kabupaten/kota. Daerah persiapan adalah bagian dari satu atau lebih daerah yang bersanding yang dipersiapkan untuk dibentuk menjadi daerah baru. Pembentukan daerah persiapan sebagaimana dimaksud harus memenuhi persyaratan dasar dan persyaratan administratif. Selain itu belum adanya Peraturan Pemerintah turunan dari PP No.78/2007 Tentang tata cara pembentukan, penghapusan, dan penggabungan daerah sebagai regulasi atau acuan yang tegas terhadap UU No.23/2014 Tentang Pemerintahan Daerah.

Kabupaten Bungo merupakan salah satu Kabupaten di Provinsi Jambi. Kabupaten ini berasal dari hasil pemekaran Bungo Tebo pada tanggal 12 Oktober 1999. Secara administratif kabupaten ini terdiri dari 17 Kecamatan dan 153 desa/kelurahan. Kabupaten Bungo memiliki kekayaan alam yang melimpah diantaranya sektor perkebunan yang ditopang oleh karet dan kelapa sawit dan sektor pertambangan ditopang oleh batubara. Selain itu Kabupaten Bungo juga kaya akan emas yang tersebar hampir di seluruh wilayah Kabupaten Bungo. Kabupaten Bungo akan dimekarkan dengan membentuk wilayah administratif baru yaitu Kabupaten Bungo dan Kota Muara Bungo. Selain kabupaten Bungo juga ada kabupaten lain yang akan dimekarkan di wilayah Provinsi Jambi yaitu Kabupaten Merangin dan Kabupaten Kerinci, tiga kabupaten ini sudah mengusulkan untuk pemekaran ke pemerintah pusat.

Mengingat tujuan otonomi daerah adalah untuk meningkatkan kesejahteraan masyarakat, mendekatkan pelayanan umum, dan memperkuat daya saing daerah maka pemekaran daerah akan mengancam penyelenggaraan pemerintah daerah dan tingkat kesejahteraan masyarakat. Dengan berpegang pada prinsip pembentukan daerah baru berpotensi meningkatkan pelayanan terhadap rakyat, alasan lainnya adalah bahwa daerah tersebut diharapkan lebih produktif dan lebih berkembang. Pemekaran daerah bertujuan utama agar ada ruang partisipasi bagi politik daerah serta masuknya uang dari pusat ke daerah. 
Namun, untuk melakukan pemekaran pada suatu daerah harus ada sosialisasi secara komprehensif terlebih dahulu kepada masyarakat yang meginginkan pemekaran tentang masalah yang harus dihadapi setelah pemekaran. Sebab, pemekaran daerah tidaklah mudah dan murah. Pemekaran daerah seharusnya menjadi solusi atas suatu permasalahan yang dihadapi, bukannya justru menambah masalah atau menciptakan masalah baru. Tujuan dari pemekaran tersebut tidak akan tercapai jika tidak disiapkan secara serius. Masyarakat justru akan memperoleh pelayanan yang semakin buruk, birokrasi daerah tidak mampu memenuhi semua jenis layanan, dan insfrastruktur dasar tidak tersedia dengan baik. Jika insfrastruktur belum tersedia, maka kepala daerah baru hanya akan disibukan untuk membenahi urusan ini dan melupakan persoalan sehari-hari masyarakat.

Rencana pemekaran Kabupaten Bungo menjadi dua wilayah yaitu Kabupaten Bungo dan Kota Muara Bungo adalah sebuah rencana yang harus dikaji lebih dalam, mengingat hasil pemekaran kabupaten baru harus dapat berjalan efektif menuju kesejahteraan rakyat. Secara umum proses munculnya isu pemekaran Kabupaten Bungo telah berlangsung lama, usulan pemekaran inipun sudah dilakukan sejak adanya PP No.129/2000 dan PP No.78/2007. Namun hingga kini usulan pemekaran tersebut masih dalam tahap proses, berbagai macam isupun telah muncul dalam proses pemekaran ini, dari adanya isu pembatalan pemekaran, penundaan pemekaran hingga diproses ulang dari tahap nol. Sehingga proses perencanaan pemekaran ini dipertanyakan. Sementara secara administratif pemekaran Kabupaten Bungo sudah diakui oleh pusat dan bisa diprioritaskan untuk dimekarkan

Sehubungan dari latar belakang tersebut ditarik masalah penelitian sebagai berikut bagaimana agenda setting kebijakan dalam pembentukan Daerah Otonomi Baru di Kabupaten Bungo, dimana tujuan dari agenda setting ini adalah untuk melihat sejauh mana isu yang sebelumnya dianggap penting menjadi isu publik kemudian masuk menjadi agenda kebijakan hingga akhirnya berhasil menjadi kebijakan publik oleh pemerintah. Seperti yang telah diketahui bahwa proses perencanaan pemekaran yang ada di kabupaten Bungo ini sudah berlangsung sangat lama namun belum diketahui sampai dimana proses ini berlangsung, sehingga nantinya peneliti bisa melihat faktor-faktor pada agenda 
setting yang menghambat tahap-tahap perumusan kebijakan pembentukan Daerah Otonomi Baru di Kabupaten Bungo

\section{METODE PENELITIAN}

Penelitian ini menggunakan pendekatan deskriptif kualitatif. Teknik pengumpulan data dilakukan dengan metode wawancra, observasi, dan dokumentasi. Lokasi penelitian di Kbupaten Bungo Provinsi Jambi.

Fenomena yang diamati dalam penelitian ini meliputi yaitu : mendeskripsikan agenda setting kebijakan pembentukan DOB dengan melihat tahap-tahap kebijakan yang terdiri dari : Isu publik, agenda pemerintah, keputusan politik, penetapan kehendak, dan legitimasi.

Faktor-faktor apa pada agenda setting yang diduga menjadi penghambat tahap-tahap perumusan kebijakan pembentukan DOB, jika dilihat dari factorfaktor: (a). Secara persyaratan sesuai PP No.78/2007 tentang tata cara pembentukan, penghapusan dan penggabungan daerah. (b). aktor-aktor yang terkait dalam tahap-tahap perumusan kebijkan pembentukan DOB. (c). Moratorium pemekaran daerah terhadap UU No.23/2014 Tentang Pemerintahan Daerah.

Teknis analisis data dilakukan melalui empat tahap, yaitu: pengumpulan data, reduksi data, display data dan penarikan kesimpulan. Kemudian untuk menguji keabsahan data Peneliti Menggunakan teknik triangulasi.

\section{HASIL DAN PEMBAHASAN}

\section{Analisis Agenda Setting Kebijakan Pembentukan Daerah Otonomi Baru 1) Isu Publik}

Isu-isu yang berkembang serta pendapat dari berbagai forum seperti media massa, aspirasi masyarakat, seminar, lokakarya, Ormas, tokoh masyarakat, elit politik, kelompok yang berkepentingan dalam proses waktu akan mengkristal dalam berbagai pendapat publik dan mendorong terjadinya identifikasi atas isu berdasarkan urgensi dan prioritasnya hingga tersetting dalam suatu agenda yang memerlukan tindak lanjut pemecahannya. Urgensinya persoalan yang telah tersetting oleh publik mendorong pemerintah sebagai pemegang otoritas dalam kehidupan publik menjadikan persoalan 
yang telah tersetting menjadi agenda yang harus diselesaikan melalui kebijakan yang harus diperlakukan.

Isu Publik pemekaran Kabupaten Bungo terbukti dengan adanya aspirasi masyarakat dalam pemekaran wilayah Kabupaten Bungo, namun dalam hal ini isu tersebut telah menjadi keputusan bersama yaitu kehendak masyarakat dan pemerintah itu sendiri yang dimulai sejak tahun 2004, dan telah terbukti sebagaimana telah tertuang dalam Keputusan Badan Permusyawaratan Dusun (BPD) dan Forum Komunikasi Kelurahan (FKK) dalam wilayah calon Kota Muara Bungo.

\section{2) Agenda Pemerintah}

Agenda pemerintahan akan dirumuskan sebagai suatu kebijakan sekaligus perumusan kegiatan dalam program untuk kemudian dituangkan ke dalam aturan dan hukum sesuai kebutuhan berdasarkan aturan perundangundangan.

Agenda pemerintah adalah Dokumen-dokumen tahapan pemekaran daerah Kabupaten Bungo yang telah masuk dalam agenda pemerintah daerah Kabupaten Bungo. agenda pemerintah terkait pembentukan DOB berdasarkan persyaratan Administrasi sesuai PP No.78/2007 telah berjalan dengan baik yaitu adanya surat persetujuan dari pihak Pemerintah Daerah, DPRD Kabupaten Bungo, DPRD Provinsi Jambi dan Gubernur Jambi serta telah sampai pada tahap akhir yaitu disampaikannya surat usulan pemekaran daerah oleh Gubernur Jambi kepada Presiden melalui Kemendagri pada tahun 2012.

\section{3) Kesepakatan Politik}

Pengagendaan pemerintah melalui kebijakan yang akan diperlakukan memerlukan kesepakatan politik dari lembaga politik yang ada seperti lembaga perwakilan publik (DPR/D). Perumusan kebijakan sebagai pengembangan terhadap alternatif pemecahan masalah pemekaran daerah Kabupaten Bungo ada pada keputusan pihak Yudikatif (pemerintah pusat) yaitu adalah sebagai berikut:

a) DPR RI telah memutuskan Kabupaten Bungo masuk dalam 65 RUU DOB urutan Ke enam.

b) Telah dilakukan observasi lapangan oleh Kemendagri dan hasil dari observasi lapangan tersebut ditemukan adanya persyaratan secara fisik 
yang belum sesuai oleh daerah Kabupaten Bungo yaitu masalah sarana dan prasarana dan tanda kepemilikan batas wilayah.

c) Adanya moratorium pemekaran daerah terhadap UU No.23/2014 Tentang Pemerintahan Daerah. Dalam hal ini Kabupaten Bungo belum melakukan tahapan daerah persiapan dikarenakan belum adanya Peraturan Pemerintah sebagai penyanding daripada UU No.23/2014 tersebut.

\section{4) Legitimasi}

Hasil daripada perumusan kebijakan itulah yang merupakan komitmen secara normatif dirumuskan ke dalam bentuk aturan hukum sesuai tata aturannya.

Hasil dari perumusan kebijakan tentang tahapan pembentukan Daerah Otonomi Baru Kabupaten Bungo atau komitmen secara normatif dirumuskan kedalam bentuk program pemerintah daerah Kabupaten Bungo yaitu program Pembangunan Jangka Menengah Daerah (RPJMD) Kabupaten Bungo Tahun 2016-2021 yang merupakan tahapan lima tahun ketiga dalam rangka mewujudkan visi dari RPJPD Kabupaten Bungo Tahun 2006-2026.

Pelaksanaan tahapan pemekaran daerah Kabupaten Bungo selanjutnya tertuang pada Misi Daerah Kabupaten Bungo Nomor 3 yaitu meningkatkan tata kelola pemerintahan yang baik berorientasi pada pelayanan publik yang arah kebijakannya untuk penyelesaian tahapan proses pemekaran daerah Kabupaten Bungo.

Faktor-faktor pada agenda setting yang menghambat tahap-tahap perumusan kebijakan dalam pembentukan Daerah Otonomi Baru

1) Persyaratan Pembentukan DOB sesuai Peraturan Pemerintah Nomor 78 Tahun 2007

PP No.78/2007 Tentang Tata cara Pembentukan, penghapusan dan pengabungan daerah merupakan pengganti PP No.129/2000 yang sudah tidak sesuai lagi dengan perkembangan ketatanegaraan dan tuntutan penyelenggaraan otonomi daerah sehingga perlu diganti.

Dalam pembentukan daerah ada tiga persyaratan menurut PP No.78/2007 Tentang Tata cara Pembentukan, penghapusan dan penggabungan daerah yang harus dipenuhi oleh calon Kabupaten/Kota yang akan dimekarkan menjadi dua Kabupaten/Kota yaitu syarat administratif, 
syarat Teknis dan syarat fisik kewilayahan. Kemudian Daerah yang dibentuk dapat dimekarkan setelah mencapai batas minimal usia penyelenggaraan pemerintahan 7 (tujuh) tahun bagi kabupaten dan kota dan juga harus memenuhi beberapa tata cara pembentukan Daerah Kabupaten/Kota.

Kabupaten Bungo telah melengkapi persyaratan secara administrasi dan teknis, namun belum menyelesaikan persyaratan secara fisik yaitu belum ditetapkannya lokasi calon ibukota dan kabupaten, kemudian belum ditentukannya sarana prasarana calon wilayah Kabupaten Bungo dan calon wilayah kota Muara Bungo serta belum adanya tanda kepemilikan tanah dari pemerintah daerah itu sendiri. Kemudian usia penyelenggaraan pemerintahan Kabupaten Bungo sudah dilaksanakan semenjak tahun 2004, jadi untuk usia penyelenggaraan pemerintahan Kabupaten Bungo dalam pembentukan DOB hingga sekarang kurang lebih sudah berusia 12 tahun.

2) Aktor-aktor yang terkait dalam tahap-tahap perumusan kebijakan pembentukan Daerah Otonomi Baru

Mengenai bahasan kebijakan publik, aktor sangat mempunyai posisi strategis bersama dengan kelembagaan kebijakan. Hubungan aktor dan kelembagaan ialah penentu proses perjalanan dinamika dan strategi yang dilakukan oleh ruang lingkup kebijakan. Prinsipnya aktor kebijakan adalah orang, baik sebagai perumus maupun kelompok penekan kebijakan yang proaktif dan aktif dalam interaksi di dalam analisis kebijakan publik.

Kelompok resmi dalam tahapan pembentukan Daerah Otonomi Baru di Kabupaten Bungo adalah Pemerintah Daerah Kabupaten Bungo dan DPRD Kabupaten Bungo. Selanjutnya Kelompok tidak resmi dalam tahapan Pembentukan DOB Kabupaten Bungo adalah Organisasi Masyarakat dan LSM. Dalam tahapan pembentukan DOB kelompok resmi yaitu Kepala Daerah Kabupaten Bungo menangguhkan pemekaran Kabupaten Bungo pada tahun 2013 dengan mengeluarkan Surat Bupati perihal Pemekaran wilayah Kabupaten Bungo. Kemudian munculnya rasa kekecewaan terhadap keputusan tersebut dari kalangan legislatif dan Ormas/LSM.

3) Moratorium Pemekaran Daerah Terhadap Undang-Undang Nomor 23 Tahun 2014 Tentang Pemerintahan Daerah

UU No.23/2014 merupakan hasil revisian dari UU No.32/2004 Tentang Pemerintahan Daerah. Dengan telah terbitnya UU No.23/2014, maka 
kebijakan penataan daerah yang mencakup pembentukan dan penyesuaian daerah mengacu pada Undang-undang tersebut.

Perbedaan persyaratan pembentukan DOB pada UU No.23/2014 dengan persyaratan pembentukan DOB pada PP No.78/2007 yaitu dengan adanya tambahan persyaratan tahap daerah persiapan selama 3 tahun dengan memenuhi persyaratan dasar yang meliputi persyaratan dasar kewilayahan dan persyaratan dasar kapasitas daerah serta persyaratan administratif.

Selanjutnya terkait dengan persyaratan pembentukan Daerah menurut UU No.23/2014 yaitu adanya tahapan daerah persiapan selama 3 tahun Kabupaten Bungo belum melakukan tahapan persiapan tersebut dikarenakan belum adanya Peraturan Pemerintah penyanding daripada Undang-undang tersebut pengganti PP No.78/2007. Jadi persyaratan pembentukan DOB Kabupaten Bungo masih mengarah pada persyaratan PP No.78/2007

\section{KESIMPULAN DAN SARAN}

\subsection{KESIMPULAN}

Berdasarkan uraian hasil penelitian dan pembahasan tentang analisis agenda setting kebijakan pembentukan Daerah Otonomi Baru di Kabupaten Bungo yang telah diuraikan pada Bab IV, maka diperoleh beberapa kesimpulan yaitu:

1) Hasil analisis Agenda setting kebijakan pembentukan DOB Kabupaten Bungo merupakan proses perumusan kebijakan yang perjalanannya cukup panjang yang telah dilewati dan tidak terbilang mudah berawal dari isu sampai pada tahapan keputusan- keputusan pemerintah daerah yang memutuskan pemekaran daerah Kabupaten Bungo menjadi dua wilayah administartif walaupun dasar tersebut didasarkan jika ditarik benang merahnya melalui analisis agenda setting hal demikian muncul dari aktor daerah (Bupati) dan didukung oleh aspirasi masyarakat serta kelompok kepentingan lainya yang berusaha mengawali hingga sampai pada tingkatan pusat. 
2) Faktor-faktor pada agenda setting yang menghambat tahap-tahap perumusan kebijakan dalam pembentukan Daerah Otonomi Baru di Kabupaten Bungo, diantaranya dilihat dari:

a) Persyaratan pembentukan DOB berdasarkan PP No.78/2007

Kabupaten Bungo telah melengkapi persyaratan secara administrasi dan teknis, namun belum menyelesaikan persyaratan secara fisik kewilayahan yaitu belum menyediakan bangunan dan lahan untuk perkantoran calon Kabupaten Bungo dan calon bangunan dan lahan untuk perkantoran Kota Muara Bungo. Selanjutnya belum terselesaikannya masalah batas wilayah antara Kabupaten Bungo dengan Kabupaten Tebo Provinsi Jambi dan Kabupaten Bungo dengan Kabupaten Dhamasraya Provinsi Sumatera Barat, sehingga belum adanya tanda kepemilikan yang sah dari Pemerintah Daerah Kabupaten Bungo. Melihat pada proses persyaratan pemekaran Kabupaten Bungo terdapat politik kepentingan elit didalamnya, karena dilihat dari persyaratan Peraturan Pemerintah No.78/2007 dalam hal ini aktor daerah mengabaikan syarat fisik kewilayahan, selanjutnya dilihat dari usia penyelenggaraan pemerintahan Kabupaten Bungo sudah dilaksanakan semenjak tahun 2004, jadi untuk usia penyelenggaraan pemerintahan Kabupaten Bungo dalam pembentukan DOB hingga tahun 2016 kurang lebih sudah berusia dua belas tahun.

b) Aktor-aktor yang terkait dalam tahap-tahap perumusan kebijakan pembentukan Daerah Otonomi Baru (DOB) di Kabupaten Bungo.

Kelompok resmi dalam tahapan pembentukan Daerah Otonomi Baru di Kabupaten Bungo adalah Pemerintah Daerah Kabupaten Bungo dan DPRD Kabupaten Bungo. Selanjutnya Kelompok tidak resmi dalam tahapan Pembentukan DOB Kabupaten Bungo adalah Organisasi Masyarakat dan LSM. Dalam tahapan pembentukan DOB kelompok resmi yaitu Kepala Daerah Kabupaten Bungo menangguhkan pemekaran Kabupaten Bungo pada tahun 2013 dengan mengeluarkan Surat Bupati perihal Pemekaran wilayah Kabupaten Bungo. Kemudian munculnya rasa kekecewaan terhadap keputusan tersebut dari kalangan legislatif dan Ormas/LSM Kabupaten Bungo. 
c) Moratorium pemekaran daerah terhadap Undang-undang Nomor 23 Tahun 2014 Tentang pemerintahan daerah.

Terkait dengan persyaratan pembentukan Daerah menurut Undangundang Nomor 23 Tahun 2014 yaitu adanya tahapan daerah persiapan selama 3 tahun Kabupaten Bungo belum melakukan tahapan daerah persiapan tersebut dikarenakan belum adanya Peraturan Pemerintah penyetara daripada Undang-undang tersebut pengganti PP No.78/2007. Jadi persyaratan pembentukan DOB Kabupaten Bungo masih mengarah pada persyaratan PP No.78/2007 Tentang Tata Cara Pembentukan, Penghapusan dan Penggabungan Daerah.

\subsection{SARAN}

Berdasarkan kesimpulan di atas, maka dalam analisis agenda setting kebijakan pembentukan DOB Kabupaten Bungo dapat disarankan sebagai berikut:

1) Dalam merencanakan pembentukan DOB perlu Pemerintah Daerah Kabupaten Bungo terlebih dahulu menyelesaikan masalah batas wilayah antara Kabupaten Bungo dengan Kabupaten Tebo Provinsi Jambi dan antara Kabupaten Bungo dengan Kabupaten Dhamasraya Provinsi Sumatera Barat, sehingga adanya bukti kepemilikan batas wilayah yang sah oleh Pemerintah Kabupaten Bungo. Kemudian perlu adanya bangunan dan lahan untuk perkantoran calon Kabupaten Bungo dan calon bangunan dan lahan untuk perkantoran Kota Muara Bungo sebagai persyaratan fisik kewilayahan. Jadi perlunya keseriusan pemerintah daerah Kabupaten Bungo dalam menyelesaikan masalah perbatasan wiayah yang sudah memakan waktu yang cukup lama.

2) Dalam mengambil keputusan menangguhkan pemekaran wilayah terjadi miss komunikasi. Sehingga kurangnya koordinasi antara pemerintah daerah dan Legislatif Kabupaten Bungo serta kelompok kepentingan lainnya terkait keputusan perencanaan pemekaran wilayah Kabupaten Bungo. 


\section{DAFTAR PUSTAKA}

Abdullah, HI.M, Resolusi Konflik Antara Utama Pemekaran Di Administrasi Pemerintah Daerah Di Indonesia, Journal of law, policy and globalization, volume 38, 2015

BPS provinsi Jambi Dalam Angka 2015.

BPS Kabupaten Bungo Dalam Angka 2012 s/d 2016

Departemen Pendidikan Nasional, 2008, Kamus Besar Bahasa Indonesia Pusat Bahasa, Edisi ke empat, Gramedia Pustaka Umum, Jakarta

Dunn, William N, 2000, Pengantar Analisis Kebijakan Publik, Edisi Kedua, Gadjah Mada University Press, Yogyakarta.

Faried Ali, Andi Syamsu Alam, 2012, Studi Kebijakan Pemerintah, Edisi Pertama, Refika Aditama, Bandung

Febriyandi, Didi, Proses Perumusan Kebijakan Pemekaran Daerah (studi di Pulau Sebatik Kabupaten Nanukan Kalimantan Utara), Jurnal IImiah Administrasi Publik (JIAP), Vol: 2 Nomor 2 (2016)

Harian Jambi Ekspress, Edisi 07 Januari 2015

Harian Tribun Jambi, Edisi 1 Februari 2016

Harian Tribun Jambi, Edisi 24 Februari 2016

Irawan, Tujuan Pemerintah Sentral dalam Pembentukan Daerah Otonomi Baru di Bandung Barat, Jurnal International, Indonesia Muda Institute, Jakarta, Indonesia,2011

Imran, M.Ali, Otonomi Daerah, Pemekaran Daerah dan Pemerintah Daerah semu di Indonesia, Journal International, Ritsumeikan Asia Pacific University, Japan, Volume 1, 2011

Irman Salaputra, Muhlis Madani, Andi Luhur Prianto, Peran aktor dalam penyusunan agenda kebijakan pemekaran wilayah kecamatan di Kabupaten Maluku Tengah, Jurnal Otoritas, Volume III Nomor 1, Universitas Muhammadiyah Makassar. 2013

Lembaga Administrasi Negara RI, 2008, Analisis Kebijakan Publik (Modul Pendidikan Pelatihan Kepemimpinan Tingkat III), ISBN : 979-8619-62-5, Jakarta

Moleong, Lexy J. (2007) Metodologi Penelitian Kualitatif, Penerbit PT Remaja Rosdakarya Offset, Bandung 
Nugroho, Riant, 2013, Metode Penelitian Kebijakan, cetakan kedua, Pustaka Pelajar, Yogyakarta

Pasolong, Harbani, 2012, Metode Penelitian Administrasi Publik, Alfabeta, Bandung

Pariabo, Yoram, Studi Kelayakan Pemekaran Kabupaten Swandiwe dari Kabupaten Biak Numfor Provinsi Papua, Jurnal Ilmu Pemerintahan, 2013

Sugiyono, 2014, Memahami Penelitian Kualitatif, Cetakan Kesepuluh, Alfabeta, Bandung

Suwitri, Sri, 2011, Konsep Dasar Kebijakan Publik, Undip, Semarang.

Swasanany, Titi W, Proses Formulasi Kebijakan Daerah Otonomi Baru di Indonesia (Perspektif Democratic Governance), Jurnal Kajian Vol. 18 Nomor 2, 2013

Tresiana, Novita, Rasionalitas Kebijakan Pemekaran, Kecamatan dan Kelurahan di Kota Bandar Lampung, Jurnal FISIP Universitas Lampung, 2015

Trisnawati, Dian, Pemekaran Daerah di Kabupaten Bintan (Studi Kasus Pemekaran Kabupaten Bintan Timur), Jurnal IImu Pemerintahan FISIP Umrah Tanjung Pinang, 2014

Wahab, Abdul S, 2016, Analisis Kebijakan Publik, Edisi Keempat, cetakan keempat, Bumi Aksara, Jakarta

Winarno, Budi, 2014, Kebijakan Publik (Teori, Proses, dan Studi Kasus), Edisi Kedua, CAPS, Yogyakarta

Zulkarnain, Ariandi, Dinamika Proses Pemekaran Kecamatan Sentajo Raya Kabupaten Kuantan Singingi Tahun 2008-2012, Jurnal IImu Pemerintahan FISIP Universitas Riau.

\section{PERATURAN :}

Undang-undang Nomor 23 tahun 2014 Tentang Pemerintahan Daerah

Peraturan Pemerintah Nomor 78 Tahun 2007 Tentang Tata Cara Pembentukan, Penghapusan dan Penggabungan Daerah

Peraturan Bupati Bungo Nomor 55 Tahun 2016 Tentang Susunan Organisasi, Tugas dan Fungsi, Serta Bagan Struktur Sekretariat Daerah Kabupaten Bungo 
Peraturan Bupati Bungo Nomor 51 Tahun 2016 Tentang Susunan Organisasi, Tugas dan Fungsi, serta Baga Struktur Badan Perencanaan Pembangunan Daerah Kabupaten Bungo.

Peraturan Bupati Bungo Nomor 17 Tahun 2014 Tentang Uraian Tugas Pokok dan Fungsi Badan Penanggulangan Bencana Daerah, esatuan Bangsa, dan Politik Kabupaten Bungo.

Peraturan Daerah Kabupaten Bungo Nomor 8 Tahun 2016 Tentang Rencana Pembangunan Jangka Menengah Daerah Kabupaten Bungo Tahun 2016-2021. 